\title{
Photo-Oxidation Coupled Kabachnik-Fields and Bigenelli Reactions for Direct Conversion of Benzyl alcohols to $\alpha$-Aminophosphonates and Dihydropyrimidones
}

\author{
Gazunfor Ali, ${ }^{1}$ Nisar A. Dangroo,,${ }^{1,2,}$ Shabnam Raheem, ${ }^{2}$ Tahira Naqvi, ${ }^{3}$ \\ Tabassum Ara ${ }^{1}$ and Masood Ahmad Rizvi ${ }^{2, *}$ \\ ${ }^{1}$ Department of Chemistry, National Institute of Technology, Srinagar 190006, India \\ ${ }^{2}$ Department of Chemistry, University of Kashmir, Srinagar 190006, India. \\ ${ }^{3}$ Department of Chemistry, Government Degree College for Women M. A. Road, Srinagar, J\&K, India. \\ *Corresponding author: E-mail: nisar@nitsri.net, masoodku2@gmail.com
}

Received: 06-21-2019

\begin{abstract}
A tandem one-pot solvent free approach for the direct conversion of benzyl alcohols to $\alpha$-amino phosphonates and dihydropyrimidones is reported. The method relies on a metal free photo-oxidation of benzyl alcohols to benzaldehydes under UV irradiation using ammonium perchlorate followed by Kabachnik-Fields and Biginelli reactions. The reaction conditions are moderate and metal free with good substrate scope. The control experiments were performed to investigate the role of the ammonium perchlorate and molecular oxygen as oxidants. The quenching experiments in the presence of TEMPO and other radical quenchers suggest radical based mechanism.
\end{abstract}

Keywords: One-pot synthesis; photo-oxidation; benzyl alcohol; kabachnik-Fields reaction; biginelli reaction.

\section{Introduction}

The a-aminophosphonates are core structural components of many pharmacologically active molecules exhibiting diverse range of biological activities such as anticancer, HIV protease inhibitors, and serve as surrogates of $\alpha$-amino acids. ${ }^{1-3}$ The Pudovik reaction ${ }^{4}$ and KabachnikFields reactions ${ }^{5}$ involving nucleophilic addition of phosphite to imines are the most widely used methods for the synthesis of $\alpha$-aminophosphonates. The aminophosphonates can also be synthesised via acid-catalyzed (Lewis/ Brønsted), ${ }^{6,7}$ catalyst-free, ${ }^{8}$ microwave assisted ${ }^{9}$ condensation of H-phosphonates with aldehydes or imines. Furthermore, synthesis of $a$-aminophosphonates has also been achieved from substrates other than aldehydes using methylene aziridines ${ }^{10}$ dehydrogenative $\alpha$-phosphonation of substituted $\mathrm{N}, \mathrm{N}$-dialkylanilines, ${ }^{11}$ reduction of aryl nitro compounds, ${ }^{12}$ reductive phosphination of amides, ${ }^{13}$ and biomass-derived hydroxyl methyl furfural. ${ }^{14}$ As such, we were particularly intrigued to explore the feasibility of ubiquitously available benzyl alcohols as substrates for the synthesis of $\alpha$-aminophosphonates. To the best of our knowledge only report employing the use of benzyl alcohol has been carried out with an expensive gold supported catalyst. ${ }^{15}$ Moreover, we wanted to examine if the benzyl alcohol could also serve as a surrogate of benzaldehydes for related reactions like Biginelli reaction leading to the formation of 1,4-dihydropyrimidones. Notably, 1,4-dihydropyrimidones are also a well known class of biologically active compounds with a range of therapeutic properties. ${ }^{16}$ The traditional synthesis of dihydropyrimidones involves use of an aldehyde, a $\beta$-keto ester or $\beta$-diketone, and urea, ${ }^{17}$ with most of the advances involving use of a Brønsted acid ${ }^{18}$ or base, ${ }^{19}$ metal based Lewis acids, ${ }^{20}$ organocatalysts, ${ }^{21}$ and heterogeneous catalysts. ${ }^{22-25}$

In this regard, photochemical reactions are undoubtedly greener alternatives to thermal processes, shifting the synthetic path of reaction from its solvo-thermal form to a neat and photochemical form; this has become a major step towards ecofriendly synthetic methodologies. The ap- 

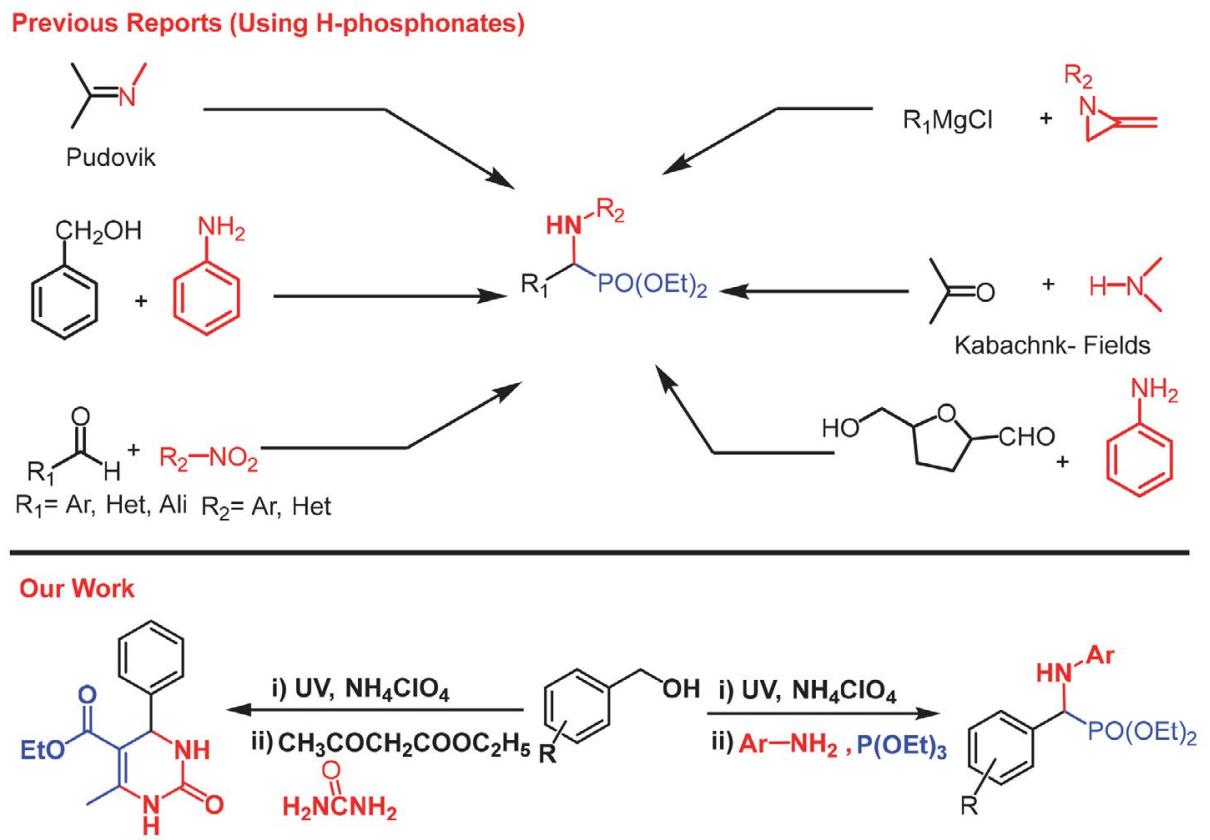

Scheme 1. General synthetic pathways and reactions described in this work

plications of photocatalysis have increased significantly in recent times and development of light mediated reactions as sustainable synthetic methodologies is becoming more popular. ${ }^{26,27}$ Besides the intrinsic eco-friendly nature, photochemical reactions are also interesting for introduction of newer reactivities as photon as reagent can interact directly at molecular level and often enables the reactions to take place from excited states unlike the conventional reagents. Thus, in continuation of our work on development of new synthetic methodologies, ${ }^{28-30}$ including photoredox reactions, ${ }^{31-33}$ herein we report a one-pot tandem approach involving oxidation of benzyl alcohols to benzaldehydes under UV-visible light irradiation in the presence of ammonium perchlorate as photocatalyst followed by Kabachnik-Fields and Biginelli reactions for the synthesis of $a$-aminophosphonates and dihydropyrimidones, respectively (Scheme 1). The reaction besides being photo-catalytic was carried out under neat conditions with a simple work up involving re-crystallization as the product purification step.

\section{Experimental}

All reactions were carried out in oven-dried glassware. The solvents used were purified by distillation. ${ }^{1} \mathrm{H}$ and ${ }^{13} \mathrm{C}$ NMR spectra were recorded on FT-NMR 500 and $400 \mathrm{MHz}$ instruments. Chemical data for protons are reported in parts per million (ppm, $\delta$ scale) downfield from tetramethylsilane and are referenced to the residual proton in the NMR solvent $\left(\mathrm{CDCl}_{3}, 7.26 \mathrm{ppm}\right)$. Carbon nuclear magnetic resonance spectra $\left({ }^{13} \mathrm{C}\right.$ NMR $)$ were recorded at $125 \mathrm{MHz}$ or $100 \mathrm{MHz}$ : chemical data for carbons are re- ported in parts per million (ppm, $\delta$ scale) downfield from tetramethylsilane and are referenced to the carbon resonance of the solvent. Coupling constants $(J)$ are quoted in $\mathrm{Hz}$. Mass spectra were recorded on electron ionization and electrospray ionization (ESI) modes.

\section{1. General Procedure for the Synthesis of $\alpha$-Aminophosphonates}

An equimolar mixture of benzyl alcohol $(100 \mu \mathrm{L}, 1.0$ $\mathrm{mmol}$ ) and ammonium perchlorate $(107.6 \mathrm{mg}, 1.0 \mathrm{mmol})$ were taken in oven dried round bottom flask under neat conditions. The reaction mixture was subjected to UV irradiation till complete conversion for benzyl alcohol to benzaldehyde, which was monitored by TLC. Afterwards the UV irradiation was stopped, and to the reaction mixture was added meta-bromoaniline $(158 \mu \mathrm{L}, 1.0 \mathrm{mmol})$ and triethylphosphite $(168 \mu \mathrm{L}, 1.1 \mathrm{mmol})$. The resulting reaction mixture was stirred at $50^{\circ} \mathrm{C}$ on the magnetic stirrer till the completion (monitored by TLC). Upon completion, to the crude reaction mixture was added ice cold water to precipitate the product which was finally recrystallized from ethanol to furnish the desired products $\mathbf{4 a - k}$. The spectral data for some representative compounds are shown below. The data of the known compounds matches with that of the literature reports ${ }^{34}$ (please see supporting information for list of known compounds and their references).

\section{Diethyl (((3-Bromophenyl)amino)(phenyl)methyl)phos- phonate (4a)}

Following the general procedure the reaction was carried out by taking benzyl alcohol $(100 \mu \mathrm{L}, 1.0 \mathrm{mmol})$, ammonium perchlorate $(107.6 \mathrm{mg}, 1.0 \mathrm{mmol}), 3$-bro- 
moaniline (158 $\mu \mathrm{L}, 1.0 \mathrm{mmol})$ and triethylphosphite (168 $\mu \mathrm{L}, 1.1 \mathrm{mmol})$ to obtain white crystalline compound $4 \mathrm{a}^{34 \mathrm{~g}}$ (342 mg, 93\% yield). ${ }^{1} \mathrm{H}$ NMR ( $400 \mathrm{MHz}, \mathrm{CDCl}_{3}$ ) $\delta 7.53$ $(\mathrm{d}, J=4.8 \mathrm{~Hz}, 2 \mathrm{H}), 7.40-7.31(\mathrm{~m}, 3 \mathrm{H}), 6.96(\mathrm{t}, J=8 \mathrm{~Hz}$, $1 \mathrm{H}), 6.88-6.81(\mathrm{~m}, 2 \mathrm{H}), 6.56(\mathrm{~d}, J=4.8 \mathrm{~Hz}, 1 \mathrm{H}), 4.76$ $(\mathrm{d}, J=4 \mathrm{~Hz}, 1 \mathrm{H}), 3.99(\mathrm{~m}, 4 \mathrm{H}), 1.34(\mathrm{t}, J=8.0 \mathrm{~Hz}, 3 \mathrm{H})$, $1.15(\mathrm{t}, J=8.0 \mathrm{~Hz}, 3 \mathrm{H}) ;{ }^{13} \mathrm{C} \mathrm{NMR}\left(100 \mathrm{MHz}, \mathrm{CDCl}_{3}\right)$ $\delta 170.0,148.1(2 \mathrm{CH}), 135.4,133.3,130.6(2 \mathrm{CH}), 128.9$ (2C), 116.8, 64.0, 55.3, 16.4; EIMS $m / z$ for $\mathrm{C}_{17} \mathrm{H}_{21} \mathrm{Br}-$ $\mathrm{NO}_{3} \mathrm{P}[\mathrm{M}+\mathrm{H}]^{+} 397.19$.

\section{Diethyl ((3-Bromophenyl)((4-hydroxyphenyl)ami- no)methyl)phosphonate (4b)}

Following the general procedure the reaction was carried out by taking 3-bromobenzyl alcohol $(100 \mu \mathrm{L}, 1.0$ $\mathrm{mmol})$, ammonium perchlorate $(62.5 \mathrm{mg}, 1.0 \mathrm{mmol})$, 4-aminophenol $(58 \mu \mathrm{L}, 1.0 \mathrm{mmol})$ and triethylphosphite $(97 \mu \mathrm{L}, 1.1 \mathrm{mmol})$ to obtain white crystalline compound $4 \mathbf{b}^{34 \mathrm{~b}}$ (201 mg, 91\% yield). M.p. $152-155^{\circ} \mathrm{C} ;{ }^{1} \mathrm{H}$ NMR $\left(400 \mathrm{MHz}, \mathrm{CDCl}_{3}\right) \delta 7.70(\mathrm{~s}, 1 \mathrm{H}), 7.64(\mathrm{~s}, 1 \mathrm{H}), 7.43(\mathrm{~d}$, $J=4.0 \mathrm{~Hz}, 2 \mathrm{H}), 7.25(\mathrm{~m}, 2 \mathrm{H}), 6.70(\mathrm{~d}, J=8 \mathrm{~Hz}, 2 \mathrm{H})$, $6.50(\mathrm{~d}, J=12 \mathrm{~Hz}, 2 \mathrm{H}), 4.70(\mathrm{~m}, 1 \mathrm{H}), 4.18(\mathrm{~m}, 4 \mathrm{H})$, $1.34(\mathrm{t}, J=8.0 \mathrm{~Hz}, 3 \mathrm{H}), 1.21(\mathrm{t}, J=8.0 \mathrm{~Hz}, 3 \mathrm{H}) ;{ }^{13} \mathrm{C}$ NMR $\left(100 \mathrm{MHz}, \mathrm{CDCl}_{3}\right) \delta 149.8(2 \mathrm{CH}), 139.5,138.8$, 131.3 (2C), 138.8, $122.9(2 \mathrm{CH}), 116.4,115.8(2 \mathrm{C})$, 64.1, 56.1, 16.6; EIMS $m / z$ for $\mathrm{C}_{17} \mathrm{H}_{21} \mathrm{BrNO}_{3} \mathrm{P}[\mathrm{M}+\mathrm{H}]^{+}$ 414.36 .

\section{Diethyl ((3-Bromophenyl)((2-iodophenyl)amino)meth- yl)phosphonate (4c)}

Following the general procedure the reaction was carried out by taking 3-bromobenzyl alcohol $(100 \mu \mathrm{L}, 1.0$ $\mathrm{mmol})$, ammonium perchlorate $(62.5 \mathrm{mg}, 1.0 \mathrm{mmol})$, 3-iodoaniline $(116 \mu \mathrm{L}, 1.0 \mathrm{mmol})$ and triethylphosphite $(97 \mu \mathrm{L}, 1.1 \mathrm{mmol})$ to obtain compound $4 \mathrm{c}^{34 \mathrm{f}}(203 \mathrm{mg}, 73 \%$

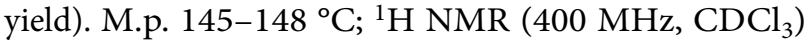
$\delta 7.72(\mathrm{~d}, J=8.0 \mathrm{~Hz}, 1 \mathrm{H}), 7.65(\mathrm{~s}, 1 \mathrm{H}), 7.45(\mathrm{~m}, 2 \mathrm{H})$, $7.29(\mathrm{~m}, 1 \mathrm{H}), 7.12(\mathrm{~m}, 1 \mathrm{H}), 6.50(\mathrm{~m}, 1 \mathrm{H}), 5.35(\mathrm{~s}, \mathrm{NH})$, $4.75(\mathrm{~m}, 1 \mathrm{H}), 4.12-3.92(\mathrm{~m}, 4 \mathrm{H}), 1.35(\mathrm{t}, J=8.0 \mathrm{~Hz}$, $3 \mathrm{H}), 1.28(\mathrm{t}, J=8.0 \mathrm{~Hz}, 3 \mathrm{H}) .{ }^{13} \mathrm{C}$ NMR $(100 \mathrm{MHz}$, $\left.\mathrm{CDCl}_{3}\right) \delta 145.7(2 \mathrm{CH}), 139.4,138.1(2 \mathrm{CH}), 131.5$, $130.5(2 \mathrm{CH}), 129.6,126.5,123.0,112.2,86.4,64.0$, 57.1, 16.6; EIMS $m / z$ for $\mathrm{C}_{17} \mathrm{H}_{20} \mathrm{BrINO}_{3} \mathrm{P}[\mathrm{M}+\mathrm{H}]^{+}$ 523.09 .

\section{Diethyl (((2-Fluorophenyl)amino)(3-nitrophenyl) methyl)phosphonate (4d)}

Following the general procedure the reaction was carried out by taking 3-nitrobenzyl alcohol $(100 \mu \mathrm{L}, 1.0$ $\mathrm{mmol})$, ammonium perchlorate $(76.4 \mathrm{mg}, 1.0 \mathrm{mmol})$, 2-fluoroaniline $(72.15 \mu \mathrm{L}, 1.0 \mathrm{mmol})$ and triethylphosphite $(118 \mu \mathrm{L}, 1.1 \mathrm{mmol})$ to obtain compound $\mathbf{4 d}^{34 \mathrm{i}}(217$ mg, $87 \%$ yield). M.p. $185-187^{\circ} \mathrm{C} ;{ }^{1} \mathrm{H}$ NMR $(400 \mathrm{MHz}$, $\left.\mathrm{CDCl}_{3}\right) \delta 8.89(\mathrm{~s}, 1 \mathrm{H}), 8.21(\mathrm{~d}, J=8 \mathrm{~Hz}, 1 \mathrm{H}), 7.90(\mathrm{~d}, J$ $=8 \mathrm{~Hz}, 1 \mathrm{H}), 7.59(\mathrm{~m}, 1 \mathrm{H}), 7.05(\mathrm{~m}, 1 \mathrm{H}), 6.90(\mathrm{~m}, 1 \mathrm{H})$, $6.73(\mathrm{~m}, 1 \mathrm{H}), 6.45(\mathrm{~m}, 1 \mathrm{H}), 5.05(\mathrm{~s}, \mathrm{NH}), 4.96-4.86$ (m, $1 \mathrm{H}), 4.09-3.96(\mathrm{~m}, 4 \mathrm{H}), 1.34(\mathrm{t}, J=4.0 \mathrm{~Hz}, 3 \mathrm{H})$, $1.26(\mathrm{t}, J=8.0 \mathrm{~Hz}, 3 \mathrm{H}) ;{ }^{13} \mathrm{C}$ NMR $\left(100 \mathrm{MHz}, \mathrm{CDCl}_{3}\right)$ $\delta$ 153.0, 151.1, 148.6, 138.6, 133.8, 129.9, 124.7, 122.9 (2C), $118.9,115.1,113.5,64.1,56.3,16.4$; EIMS $m / z$ for $\mathrm{C}_{17} \mathrm{H}_{20} \mathrm{FN}_{2} \mathrm{O}_{5} \mathrm{P}[\mathrm{M}+\mathrm{H}]^{+} 383.16$.

\section{Diethyl ((4-Fluorophenyl)amino)(3-nitrophenyl)} methyl)phosphonate (4e)

Following the general procedure the reaction was carried out by taking 3-nitrobenzyl alcohol $(100 \mu \mathrm{L}, 1.0$ $\mathrm{mmol}$ ), ammonium perchlorate $(76.4 \mathrm{mg}, 1.0 \mathrm{mmol})$, 4-fluoroaniline $(72.15 \mu \mathrm{L}, 1.0 \mathrm{mmol})$ and triethylphosphite $(118 \mu \mathrm{L}, 1.1 \mathrm{mmol})$ to obtain compound $4 \mathrm{e}^{34 a}(224$ mg, $90 \%$ yield). M.p. $179-181^{\circ} \mathrm{C}$; ${ }^{1} \mathrm{H}$ NMR $(400 \mathrm{MHz}$, $\left.\mathrm{CDCl}_{3}\right) \delta 8.34(\mathrm{~s}, 1 \mathrm{H}), 8.13(\mathrm{~d}, J=8 \mathrm{~Hz}, 1 \mathrm{H}), 7.82(\mathrm{~d}, J$ $=8 \mathrm{~Hz}, 1 \mathrm{H}), 7.50(\mathrm{~d}, J=8 \mathrm{~Hz}, 1 \mathrm{H}), 6.77(\mathrm{~d}, J=8.0 \mathrm{~Hz}$, $2 \mathrm{H}), 6.50(\mathrm{~d}, J=8.4 \mathrm{~Hz}, 2 \mathrm{H}), 4.99(\mathrm{~s}, \mathrm{NH}), 4.83(\mathrm{~m}$, $1 \mathrm{H}), 4.15-3.91(\mathrm{~m}, 4 \mathrm{H}), 1.29(\mathrm{t}, J=8.0 \mathrm{~Hz}, 3 \mathrm{H}), 1.17$ $(\mathrm{t}, J=8.0 \mathrm{~Hz}, 3 \mathrm{H}) ;{ }^{13} \mathrm{C}$ NMR $\left(100 \mathrm{MHz}, \mathrm{CDCl}_{3}\right) \delta$ $157.7,155.8,148.7,142.2(2 \mathrm{CH}), 138.9,134.0(2 \mathrm{CH})$, $129.8,123.0,116.0,115.1,64.0,55.9,16.5$; EIMS $m / z$ for $\mathrm{C}_{17} \mathrm{H}_{20} \mathrm{FN}_{2} \mathrm{O}_{5} \mathrm{P}[\mathrm{M}+\mathrm{H}]^{+} 383.31$.

\section{Diethyl ((3-Hydroxyphenyl)((3-nitrophenyl)ami- no)methyl)phosphonate (4f)}

Following the general procedure the reaction was carried out by taking 3-hydroxybenzyl alcohol $(100 \mu \mathrm{L}$, $1.0 \mathrm{mmol})$, ammonium perchlorate $(94.3 \mathrm{mg}, 1.0 \mathrm{mmol})$, 3-nitroaniline $(110 \mathrm{mg}, 1.0 \mathrm{mmol})$ and triethylphosphite $(133 \mu \mathrm{L}, 1.1 \mathrm{mmol})$ to obtain compound $4 \mathbf{f}(278 \mathrm{mg}, 91 \%$ yield). M.p. $165-167^{\circ} \mathrm{C} ;{ }^{1} \mathrm{H}$ NMR $\left(400 \mathrm{MHz}, \mathrm{CDCl}_{3}\right)$ $\delta 7.49(\mathrm{~m}, 1 \mathrm{H}), 7.40(\mathrm{~m}, 1 \mathrm{H}), 7.26(\mathrm{~s}, 1 \mathrm{H}), 7.19(\mathrm{~s}$, $1 H), 6.96(\mathrm{~d}, J=8 \mathrm{~Hz}, 2 \mathrm{H}), 6.83(\mathrm{~m}, 2 \mathrm{H}), 5.30(\mathrm{~m}$, $\mathrm{NH}), 4.78(\mathrm{~m}, 1 \mathrm{H}), 3.96(\mathrm{~m}, 4 \mathrm{H}), 1.28(\mathrm{t}, J=8.0 \mathrm{~Hz}$, $3 \mathrm{H}), 1.08(\mathrm{t}, J=8.0 \mathrm{~Hz}, 3 \mathrm{H}) ;{ }^{13} \mathrm{C}$ NMR $(100 \mathrm{MHz}$, $\left.\mathrm{CDCl}_{3}\right) \delta 157.1,156.7,149.1,147.2(2 \mathrm{CH}), 143.0$, $135.9,130.2,129.7,120.2(2 \mathrm{CH}), 115.1,108.0,64.3$, 56.3, 16.3; EIMS $m / z$ for $\mathrm{C}_{17} \mathrm{H}_{20} \mathrm{FN}_{2} \mathrm{O}_{5} \mathrm{P}[\mathrm{M}+\mathrm{H}]^{+}$ 381.10 .

\section{Diethyl ((4-Bromophenyl)amino)(4-nitrophenyl) methyl)phosphonate (4k)}

Following the general procedure the reaction was carried out by taking 4-nitrobenzyl alcohol $(100 \mu \mathrm{L}, 1.0$ $\mathrm{mmol}$ ), ammonium perchlorate $(76.4 \mathrm{mg}, 1.0 \mathrm{mmol})$, 4-bromoaniline $(112 \mu \mathrm{L}, 1.0 \mathrm{mmol})$ and triethylphosphite $(118 \mu \mathrm{L}, 1.1 \mathrm{mmol})$ to obtain compound $4 \mathbf{k}^{34 \mathrm{c}}$ (239 mg, $83 \%$ yield). M.p. $182-183^{\circ} \mathrm{C} ;{ }^{1} \mathrm{H}$ NMR $(400 \mathrm{MHz}$, $\left.\mathrm{CDCl}_{3}\right) \delta 8.18(\mathrm{~d}, J=8 \mathrm{~Hz}, 2 \mathrm{H}), 7.64(\mathrm{~d}, J=8 \mathrm{~Hz}$, $2 \mathrm{H}), 7.16(\mathrm{~d}, J=8 \mathrm{~Hz}, 2 \mathrm{H}), 6.41(\mathrm{~d}, J=8 \mathrm{~Hz}, 2 \mathrm{H}), 5.0$ $(\mathrm{m}, N H), 4.83(\mathrm{dd}, J=8.4 \mathrm{~Hz}, 1 \mathrm{H}), 4.17-3.85(\mathrm{~m}$, $4 \mathrm{H}), 1.30(\mathrm{t}, J=7.0 \mathrm{~Hz}, 3 \mathrm{H}), 1.17(\mathrm{t}, J=7.0 \mathrm{~Hz}, 3 \mathrm{H})$; ${ }^{13} \mathrm{C}$ NMR $\left(100 \mathrm{MHz}, \mathrm{CDCl}_{3}\right) \delta 147.7,144.8(2 \mathrm{CH})$, $143.6,132.1,128.6(2 \mathrm{CH}), 123.8,115.4,110.9,63.8$, 56.7, 16.4; EIMS $m / z$ for $\mathrm{C}_{17} \mathrm{H}_{20} \mathrm{BrN}_{2} \mathrm{O}_{5} \mathrm{P}[\mathrm{M}+\mathrm{H}]^{+}$ 442.02 . 


\section{2. General Procedure for the Synthesis of 1 , 4-Dihydropyrimidones}

An equimolar mixture of benzyl alcohol $(100 \mu \mathrm{L}, 1.0$ $\mathrm{mmol})$ and ammonium perchlorate $(107.6 \mathrm{mg}, 1.0 \mathrm{mmol})$ were taken in oven dried round bottom flask under neat conditions. The reaction mixture was subjected to UV irradiation till complete conversion of benzyl alcohol to benzaldehyde, which was monitored by TLC. Afterwards the UV light was stopped, and to the reaction mixture was added urea $(55.2 \mathrm{mg}, 1.0 \mathrm{mmol})$ and ethyl acetoacetate $(143.5 \mu \mathrm{L}$, $1.2 \mathrm{mmol})$. The resulting reaction mixture was stirred at $80^{\circ} \mathrm{C}$ on the magnetic stirrer till the completion of the reaction (monitored by TLC). Upon completion, to the crude reaction mixture was added ice cold water to precipitate the product which was finally recrystallized from ethanol to furnish the desired products in pure form. The spectral data for some representative compounds are shown below. The data of the known compounds matches with that of the literature reports ${ }^{35}$ (please see supporting information for list of known compounds and their references).

Ethyl 2-Methyl-6-oxo-4-phenyl-1,4,5,6-tetrahydropyridine-3-carboxylate (5a)

Following the general procedure the reaction was carried out by taking benzyl alcohol $(100 \mu \mathrm{L}, 1.0 \mathrm{mmol})$, ammonium perchlorate $(107.6 \mathrm{mg}, 1.0 \mathrm{mmol})$, urea $(55.2$ $\mathrm{mg}, 1.0 \mathrm{mmol})$ and ethyl acetoacetate $(143.5 \mu \mathrm{L}, 1.2 \mathrm{mmol})$ to obtain white crystalline compound $\mathbf{5 a}^{35 \mathrm{a}}(171 \mathrm{mg}, 71 \%$ yield). M.p. $204-206{ }^{\circ} \mathrm{C} .{ }^{1} \mathrm{H}$ NMR $\left(400 \mathrm{MHz}, \mathrm{CDCl}_{3}\right)$ $\delta 7.28(\mathrm{~s}, 1 \mathrm{H}), 5.28(\mathrm{~d}, J=8 \mathrm{~Hz}, 2 \mathrm{H}), 4.03(\mathrm{~d}, J=8 \mathrm{~Hz}$, $2 \mathrm{H}), 3.37(\mathrm{~s}, 1 \mathrm{H}), 2.15(\mathrm{~m}, 2 \mathrm{H}), 1.13(\mathrm{q}, J=6.8 \mathrm{~Hz}$, $3 \mathrm{H}) ;{ }^{13} \mathrm{C} \mathrm{NMR}\left(100 \mathrm{MHz}, \mathrm{CDCl}_{3}\right) \delta 165.3,152.1$, $148.3,144.8,128.3(2 \mathrm{CH}), 127.2(2 \mathrm{CH}), 126.2,99.2$, 59.1, 53.9, 17.7, 14.0; EIMS $m / z$ for $\mathrm{C}_{14} \mathrm{H}_{16} \mathrm{~N}_{2} \mathrm{O}_{3}$ $[\mathrm{M}+\mathrm{H}]^{+} 261.15$.

Ethyl 4-(4-Hydroxyphenyl)-2-methyl-6-oxo-1,4,5,6 -tetrahydropyridine-3-carboxylate $(5 c)$

Following the general procedure the reaction was carried out by taking 4-hydroxybenzyl alcohol $(100 \mu \mathrm{L}, 1.0$ $\mathrm{mmol}$ ), ammonium perchlorate $(93.6 \mathrm{mg}, 1.0 \mathrm{mmol})$, urea $(48 \mathrm{mg}, 1.0 \mathrm{mmol})$ and ethyl acetoacetate $(125 \mu \mathrm{L}, 1.2$ mmol) to obtain compound $5 c^{35 a}(140 \mathrm{mg}, 63 \%$ yield). M.p. $197-199^{\circ} \mathrm{C} ;{ }^{1} \mathrm{H}$ NMR $\left(400 \mathrm{MHz}, \mathrm{CDCl}_{3}\right) \delta 7.14$ $(\mathrm{d}, J=8 \mathrm{~Hz}, 2 \mathrm{H}), 6.75(\mathrm{~d}, J=8 \mathrm{~Hz}, 2 \mathrm{H}), 5.28(\mathrm{~s}, 1 \mathrm{H})$, $4.06(\mathrm{~m}, 2 \mathrm{H}), 2.34(\mathrm{~s}, 3 \mathrm{H}), 1.18(\mathrm{q}, J=6.8 \mathrm{~Hz}, 3 \mathrm{H}) ;{ }^{13} \mathrm{C}$ NMR $\left(100 \mathrm{MHz}, \mathrm{CDCl}_{3}\right) \delta 165.3,156.4,152.1,147.7$, 135.3, $127.3(2 \mathrm{CH}), 114.9(2 \mathrm{CH}), 99.6,59.0,53.3,17.7$, 14.0; EIMS $m / z$ for $\mathrm{C}_{14} \mathrm{H}_{18} \mathrm{~N}_{2} \mathrm{O}_{4}[\mathrm{M}+\mathrm{H}]^{+} 277.11$.

\section{Result and Discussion}

To begin with we evaluated the possibility of benzaldehyde formation from benzyl alcohols under visible light
(7W blue LED). The reaction of benzyl alcohol ( 1 equiv) in DMSO in the presence of $\mathrm{NH}_{4} \mathrm{ClO}_{4}$ (1 equiv) under visible light produced very low yield of product $4 a$, due to incomplete conversion of benzyl alcohol 1a to benzaldehyde (Table 1, entry 6). No substantial enhancement in the percentage yield of the product produced was observed even after employing longer reaction time using ( $7 \mathrm{~W}$ blue LED) illumination (Table 1, entry 7). Interestingly, the same reaction under UV irradiation resulted in the complete oxidation of benzyl alcohol within $3 \mathrm{~h}$ which upon addition of meta-bromoaniline and triethylphosphite produced a-aminophosphonate $\mathbf{4 a}$ in $89 \%$ yields within $4.5 \mathrm{~h}$ (Table 1 , entry 5 ). We also evaluated solvents such as acetonitrile (ACN), dichloromethane (DCM), methanol $(\mathrm{MeOH})$ and water. However, these solvents suppressed the reaction yield due to incomplete substrate conversion (Table 1, entries 1-4). Further, water proved to be a poor medium with only $45 \%$ yield of product. However, the reaction under neat (solvent free) conditions resulted in complete conversion of 1a to benzaldehyde within a relatively short time of $2.5 \mathrm{~h}$. The in situ generated aldehyde then reacts with meta bromoaniline and triethylphosphite (Kabachnik-Fields reaction) furnishing $\mathbf{4 a}$ with $93 \%$ yield in a total reaction time of $4 \mathrm{~h}$ (Table 1 , entry 8 ). The crude product was purified by simple aqueous recrystallization and hence avoiding the usage of harmful solvents and laborious work up. It was observed that UV irradiation was only important for the oxidation of benzyl alcohol to benzaldehyde in the presence of ammonium perchlorate, the second step involved stirring the reaction mixture at $50{ }^{\circ} \mathrm{C}$

Table 1. Optimization of reaction conditions for the synthesis of a-aminophosphonates

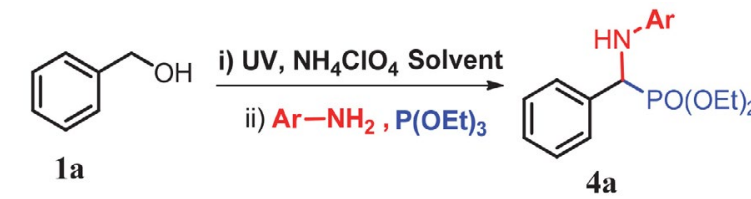

\begin{tabular}{ccccc}
\hline Entry & $\mathbf{N H}_{\mathbf{4}} \mathbf{C l O}_{\mathbf{4}}$ & Solvent & $\begin{array}{c}\text { Yield (\%) } \\
(\mathbf{4 a})^{\mathbf{a}}\end{array}$ & Time (h) \\
\hline 1 & $1.0 \mathrm{mmol}$ & ACN & 73 & 4.5 \\
2 & $1.0 \mathrm{mmol}$ & DCM & 67 & 4.5 \\
3 & $1.0 \mathrm{mmol}$ & MeOH & 59 & 4.5 \\
4 & $1.0 \mathrm{mmol}$ & Water & 41 & 4.5 \\
5 & $1.0 \mathrm{mmol}$ & DMSO & 89 & 4.5 \\
6 & $1.0 \mathrm{mmol}$ & DMSO & 13 & $9^{\mathrm{c}}$ \\
7 & $1.0 \mathrm{mmol}$ & DMSO & 15 & $24^{\mathrm{c}}$ \\
$\mathbf{8}$ & $\mathbf{1 . 0} \mathbf{m m o l}$ & Neat & $\mathbf{9 3}$ & $\mathbf{4}$ \\
9 & $0.8 \mathrm{mmol}$ & Neat & 67 & 4.5 \\
10 & $0.5 \mathrm{mmol}$ & Neat & 23 & 5 \\
11 & $0.2 \mathrm{mmol}$ & Neat & 10 & 5 \\
\hline
\end{tabular}

${ }^{a}$ All the reactions were carried out using $1.0 \mathrm{mmol}$ of benzyl alcohol, $1.0 \mathrm{mmol}$ of meta-bromoaniline and $1.1 \mathrm{mmol}$ triethylphosphite. The first step (oxidation) was conducted under UV irradiation followed by Kabachnik-Fields reaction; ${ }^{\mathrm{b}}$ Isolated yield; ${ }^{\mathrm{c}}$ The first step (oxidation) was conducted under visible light. 
over magnetic stirrer. Decreasing the $\mathrm{NH}_{4} \mathrm{ClO}_{4}$ loading resulted in attenuation in the conversion rate and the percentage yield of the reaction (Table 1, entries 9-11). In the absence of $\mathrm{NH}_{4} \mathrm{ClO}_{4}$ only traces of conversion to benzaldehyde were detected. Furthermore, in none of the experimental conditions of these reactions the formation of over-oxidized product (benzoic acid) was observed. In this synthetic methodology, the sequence of reagent addition was also found to be very important. When all the reactants were mixed at once, unnecessary longer reaction time, lower yields and complex mixture of side products were observed. The best synthetic results were obtained when the reaction was performed in a tandem one pot manner using 1.0 equiv $\mathrm{NH}_{4} \mathrm{ClO}_{4}$ under neat (solvent free) conditions.

To establish the substrate scope of the developed one-pot three component protocol for the synthesis of a-aminophosphonates, a variety of benzyl alcohols and anilines were evaluated and the results are summarized in

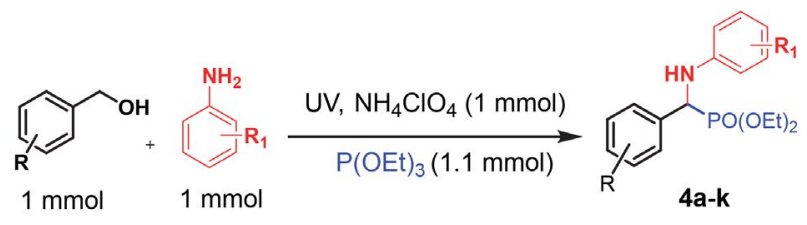

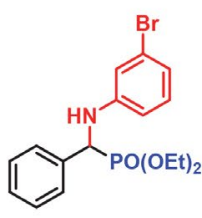

$4 a, 4.5 \mathrm{~h}, 93 \%$

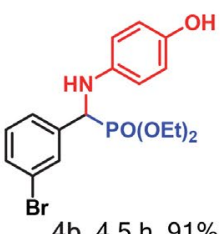

$4 b, 4.5 \mathrm{~h}, 91 \%$

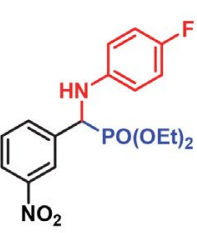

$4 \mathrm{e}, 4.5 \mathrm{~h}, 90 \%$

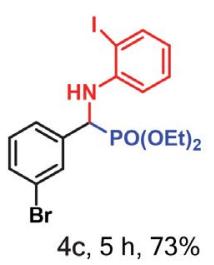

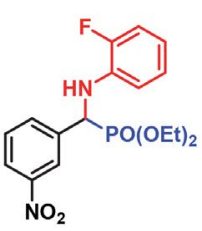

$4 \mathrm{~d}, 4.5 \mathrm{~h}, 87 \%$

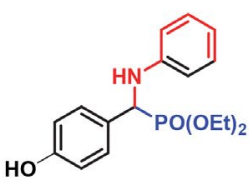

$4 h, 4.5$ h, $91 \%$

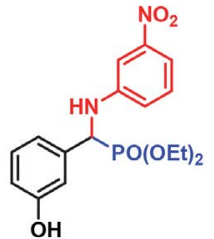

$4 f, 4.5 \mathrm{~h}, 91 \%$

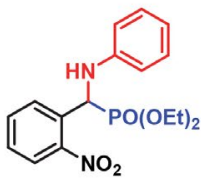

$4 \mathrm{~g}, 4.5 \mathrm{~h}, 83 \%$

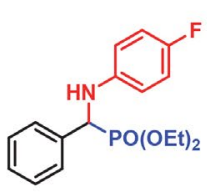

$4 \mathrm{j}, 5 \mathrm{~h}, 77 \%$

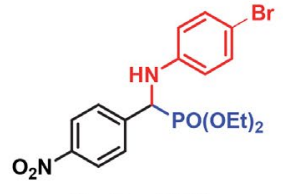

$4 k, 5$ h, $83 \%$
Scheme 2. Substrate scope for one-pot synthesis of $\alpha$-aminophosphonates from benzyl alcohols
Scheme 2. In all cases reaction proceeded smoothly and furnished the corresponding products $4 \mathbf{a}-\mathbf{k}$ in excellent yields. Unsubstituted benzyl alcohols reacted smoothly with good percentage yields (Scheme 2, 4a and $\mathbf{4 j}$ ). Irrespective of the nature of the substituent, whether electron-donating or electron-withdrawing at para position (nitro, fluoro, bromo or hydroxyl) on the benzyl alcohols or anilines, the corresponding $a$-aminophosphonates $(\mathbf{4 b}$, 4d, $4 \mathrm{e}, 4 \mathrm{~g}, 4 \mathrm{~h})$ were obtained in good to excellent yields (83-90\%). Similar trend was observed in the case of meta-substituted anilines, expected to exhibit low electronic impact on their reactivity furnishing a yield of $91 \%$ for $\mathbf{4 f}$ and $83 \%$ for $4 \mathbf{i}$. The ortho-substituted anilines needed slightly more reaction time even though their yield was comparable to that of para- and meta-substituted anilines indicating that the substitution on phenyl ring of aniline has not a very significant impact on the reaction, except in the case of ortho-iodoaniline producing $\mathbf{4 c}$ with the yield of $73 \%$. Correlating the observed trends in the percentage yields with the structural diversity of the reactants suggested that the synthetic methodology has a wider substrate scope and very little sensitivity towards electronic effects of reactants or their intrinsic reactivities.

Further to expand the applicability of our synthetic methodology, we investigated the synthesis of 1,4-dihydropyrimidones. To our delight, the treatment of benzyl alcohols with urea and ethyl acetoacetate under the previously optimized reaction conditions produced the desired 1,4-dihydropyrimidone products in good yields. The results are summarized in Scheme 3. Benzyl alcohol as well

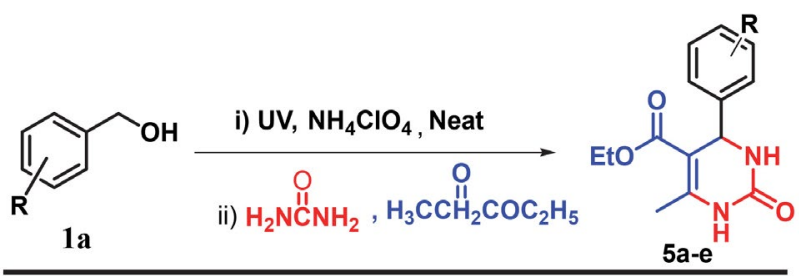<smiles>CCOC(=O)C1=C(C)NC(=O)NC1c1ccccc1</smiles>

5a, $71 \%$<smiles>CCOC(=O)C1=C(C)NC(=O)NC1c1ccc(Br)cc1</smiles>

5b, $69 \%$<smiles>CCOC(=O)C1=C(C)NC(=O)NC1c1ccc(O)cc1</smiles>

5c, $63 \%$<smiles>CCOC(=O)C1=C(C)NC(=O)NC1c1cccc(O)c1</smiles>

5d, $67 \%$<smiles>CCOC(=O)C1=C(C)NC(=O)NC1c1cccc(Br)c1</smiles>

5e, $73 \%$
Scheme 3. One pot synthesis of dihydropyrimidones from benzyl alcohols. 
Table 2. Control and quenching experiments for the oxidation of benzyl alcohol to benzaldehyde ${ }^{\mathrm{a}}$

\begin{tabular}{llll}
\hline Entry & Controlled parameter & Comments & Yield (\%) \\
\hline 1 & Optimum conditions & - & 95 \\
2 & $\mathrm{~N}_{2}$ atmosphere & - & Traces \\
3 & $\mathrm{No} \mathrm{UV} \mathrm{light}_{4}$ & - & 0 \\
4 & $\mathrm{No} \mathrm{NH}_{4} \mathrm{ClO}_{4}$ & - & 0 \\
5 & TEMPO (1eq) & radical scavenger & 13 \\
6 & tert-Butanol (leq) & hydroxide radical scavenger & 91 \\
7 & $\mathrm{NaN}_{3}($ leq) & singlet oxygen scavenger & 17 \\
8 & Benzoquinone (1eq) & superoxide radical anion scavenger & 11 \\
9 & TEMPO (leq) & radical scavenger & 13 \\
\hline
\end{tabular}

as its substituted derivatives reacted smoothly to furnish the corresponding products in excellent yields $\mathbf{5 a}-\mathbf{e}$.

Having established synthetic scheme for direct conversion of benzyl alcohol to $\alpha$-aminophosphonates and dihydropyrimidones, we became curious to explore the role of $\mathrm{NH}_{4} \mathrm{ClO}_{4}$ and the light source on the oxidation of benzyl alcohols. To arrive at mechanistic insight into the photo-oxidation step of benzyl alcohol to benzaldehyde we performed some controlled experiments summarized in Table 2. Under optimized reaction conditions $95 \%$ yield of benzaldehyde was achieved. No reaction was observed in the absence of UV light or $\mathrm{NH}_{4} \mathrm{ClO}_{4}$ (Table 2, entries 3-4). Moreover, only traces of products were formed under $\mathrm{N}_{2}$ atmosphere, which clearly indicated the significant role of $\mathrm{O}_{2}$.

The dependence of synthetic reaction on UV light and molecular oxygen was indicative of a possible radical path for the reaction. To explore the radical path, the effect of different quenchers on reaction progress was measured. ${ }^{36}$ The observed results are summarized in Table 2 (entries 5-9). When (2,2,6,6-tetramethylpiperidin-1-yl) oxyl (TEMPO) was used as a radical scavenger, only $13 \%$ benzaldehyde product was formed suggesting that the reaction pathway involved is actually the radical pathway. The use of tert-butanol as a hydroxide radical scavenger had no influence on the reaction yield inferring no involvement of the hydroxide radical in the reaction. Use of sodium azide as quencher showed the lowering in the reaction yield highlighting the involvement of singlet oxygen radical in the reaction system. Similarly using the benzoquinone as superoxide radical anion scavenger also lowered the reaction yield significantly suggesting the involvement of superoxide radical participation in the reaction mechanism.

Based on the observations of control experiments, a plausible mechanism as shown in Scheme 4 was proposed. According to the proposed mechanism, upon irradiation of UV light, $\mathrm{NH}_{4} \mathrm{ClO}_{4}$ gets electronically excited and undergoes single electron transfer (SET) to benzyl alcohol

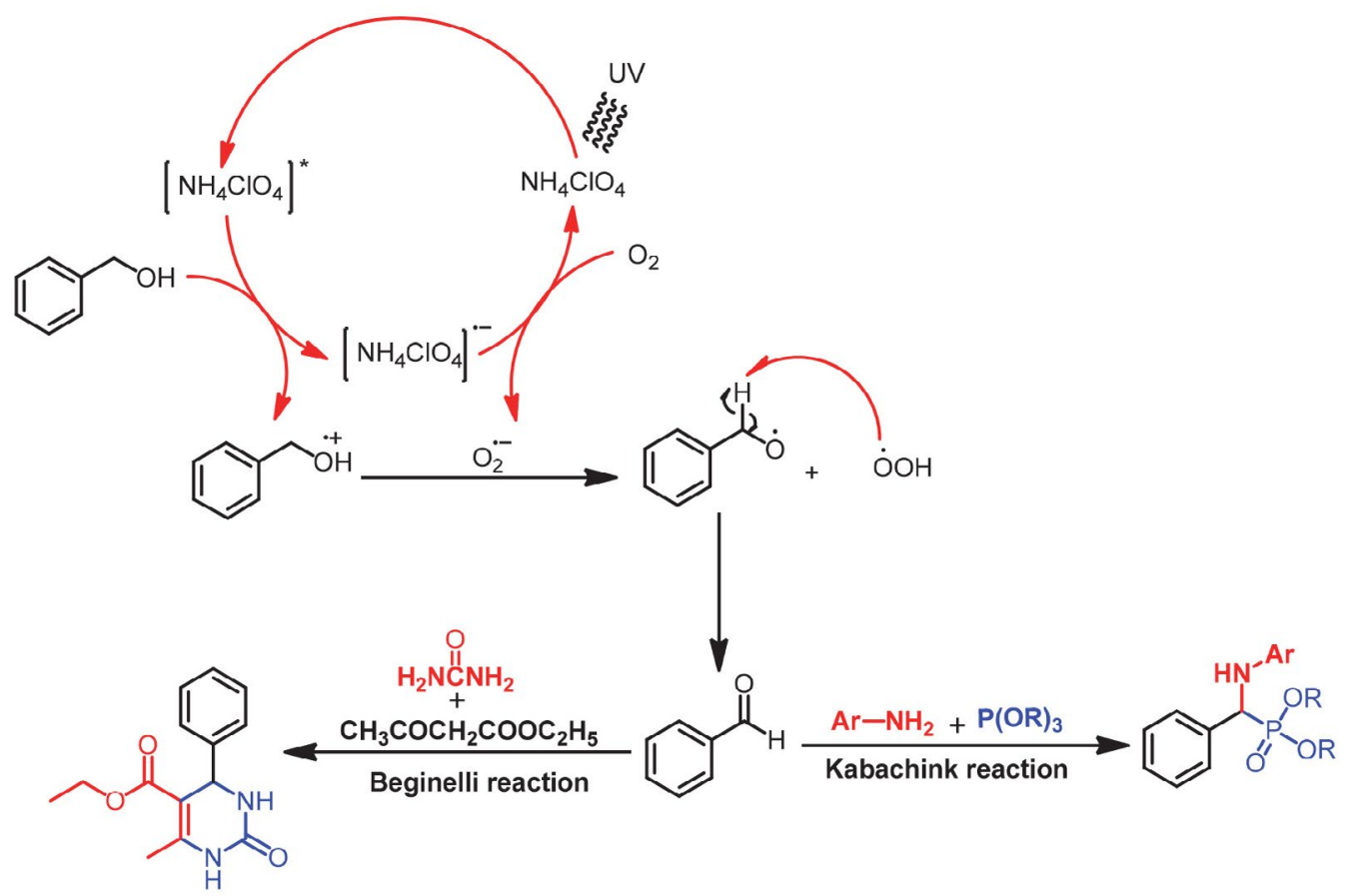

Scheme 4. Plausible mechanism for photocatalytic conversion of benzyl alcohol to $\alpha$-aminophosphonates and dihydropyrimidones. 
generating benzyl alcohol radical cation and in turn gets itself transformed to ammonium perchlorate radical anion. The ammonium perchlorate radical anion generated reacts with molecular oxygen $\mathrm{O}_{2}$ in air to produce an initial superoxide radical anion. The activated benzyl alcohol radical cation then reacts with superoxide radical $\mathrm{O}_{2}{ }^{--}$to produce peroxide radical. The generated peroxide radical abstracts hydrogen from the methylene carbon to generate the benzaldehyde molecule. The benzaldehyde then reacts with anilines and triethylphosphite to produce final aminophosphonates. Similarly the in situ generated benzaldehyde also reacts with urea and $\beta$-keto ester to produce dihydropyrimidones.

\section{Conclusion}

In summary, we have reported one-pot tandem conversion of benzyl alcohols to $\alpha$-amino phosphonates and 1,4-dihydropyrimidones. The method is based on the photo-oxidation of benzyl alcohol using $\mathrm{NH}_{4} \mathrm{ClO}_{4}$ as a commercially available and inexpensive metal-free photocatalyst for the in situ generation of benzaldehydes followed by condensation with anilines and trialkylphosphites (Kabachnik-Fields reaction) to furnish $\alpha$-aminophosphonates and also with urea and $\beta$-keto esters (Biginelli reaction) to produce 1,4-dihydropyrimidones. The detailed experimental studies indicate the role of UV light, $\mathrm{NH}_{4}$ $\mathrm{ClO}_{4}$ and $\mathrm{O}_{2}$ in the synthetic reaction. Notably, this method avoids the use of harmful organic solvents and involves photo-catalytic action. The results of controlled experiments indicate a radical based mechanism for photo oxidation of benzyl alcohol to benzaldehydes.

\section{References}

1. X.-C. Huang, M. Wang, Y.-M. Pan, G.-Y. Yao, H.-S. Wang, X.-Y. Tian, J.-K. Qin, Y. Zhang, Eur. J. Med. Chem. 2013, 69, 508-520. DOI:10.1016/j.ejmech.2013.08.055

2. Z. Rezaei, H. Firouzabadi, N. Iranpoor, A. Ghaderi, M. R. Jafari, A. A. Jafari, H. R. Zare, Eur. J. Med. Chem. 2009, 44, 4266-4275. DOI:10.1016/j.ejmech.2009.07.009

3. G. Zhang, G. Hao, J. Pan, J. Zhang, D. Hu, B. Song, J. Agric. Food Chem. 2016, 64, 4207-4213.

DOI:10.1021/acs.jafc.6b01256

4. J. P. Abell, H. Yamamoto, J. Am. Chem. Soc. 2008, 130, 1052110523. DOI: $10.1021 /$ ja803859p

5. (a) Y.-Q. Yu, D.-Z. Xu, Synthesis 2015, 47, 1869-1876.

DOI:10.1055/s-0034-1380523

(b) G. Keglevich, E. Bálint, Molecules 2012, 17, 12821-12835.

DOI:10.3390/molecules 171112821

6. (a) I. Essid, S. Touil, Curr. Org. Synth. 2017, 14, 272-278.

DOI:10.2174/1570179413666160624092814

(b) C. Qian, T. Huang, J. Org. Chem. 1998, 63, 4125-4128.

DOI:10.1021/jo971242t
7. X.-C. Li, S.-S. Gong, D.-Y.Zeng, Y.-H. You, Q. Sun, Tetrahedron Lett. 2016, 57, 1782-1785. DOI:10.1016/j.tetlet.2016.03.033

8. (a) R. M. N. Kalla, J. Bae, I. Kim, New J. Chem. 2017, 41, 6653-6660. DOI:10.1039/C7NJ00944E

(b) M. M. Kabachnik, E. V. Zobnina, I. P. Beletskaya, Synlett 2005, 1393-1396. DOI:10.1055/s-2005-868519

(c) X. Mu, M. Lei, J. Zou, W. Zhang, Tetrahedron Lett. 2006, 47, 1125-1127. DOI:10.1016/j.tetlet.2005.12.027

(d) G. Keglevich, A. Szekrenyi, Lett. Org. Chem. 2008, 5, 616622. DOI: $10.2174 / 157017808786857598$

(e) E. Bálint, E. Fazekas, P. Pongrácz, L. Kollár, L. Drahos, T. Holczbauer, M. Czugler, G. Keglevich, J. Organomet. Chem. 2012, 717, 75-82. DOI:10.1016/j.jorganchem.2012.07.031

(f) E. Bálint, E. Fazekas, G. Pintér, A. Szollosy, T. Holczbauer, M. Czugler, L. Drahos, T. Körtvélyesi, G. Keglevich, Curr. Org. Chem.2012,16,547-554. DOI:10.2174/138527212799499822 (g) E. Bálint, E. Fazekas, L. Drahos, G. Keglevich, Heteroatom Chem. 2013, 24, 510-515. DOI:10.1002/hc.21126

(h) E. Bálint, E. Fazekas, J. Kóti, G. Keglevich, Heteroatom Chem. 2015, 26, 106-115. DOI:10.1002/hc.21221

(i) P. Kafarski, M. Górny vel. Górniak, I. Andrasiak, Curr. Green Chem. 2015, 2, 218-222.

DOI:10.2174/2213346102666150109203606

(j) E. Bálint, A. Tripolszky, E. Jablonkai, K. Karaghiosoff, M. Czugler, Z. Mucsi, L. Kollár, P. Pongrácz, G. Keglevich, J. Organomet. Chem. 2016, 801, 111-121.

DOI:10.1016/j.jorganchem.2015.10.029

(k) E. Bálint, R. E. Tóth, G. Keglevich, Heteroatom Chem. 2016, 27, 323-355. DOI:10.1002/hc.21343

(l) E. Bálint, Á. Tajti, D. Kalocsai, B. Mátravölgyi, K. Karaghiosoff, M. Czugler, G. Keglevich, Tetrahedron 2017, 73, 56595667. DOI:10.1016/j.tet.2017.07.060

(m) Á. Tajti, E. Szatmári, F. Perdih, G. Keglevich, E. Bálint, Molecules 2019, 24, 1640 (13 pages).

DOI:10.3390/molecules24081640

(n) A. Tripolszky, L. Zoboki, E. Bálint, J. Kóti, G. Keglevich, Synth. Commun. 2019, 49, 1047-1054.

DOI: $10.1080 / 00397911.2019 .1584675$

9. (a) N. Azizi, F. Rajabi, M. R. Saidi, Tetrahedron Lett. 2004, 45, 9233-9236. DOI:10.1016/j.tetlet.2004.10.092

(b) E. Bálint, Á. Tajti, A. Ádám, I. Csontos, K. Karaghiosoff, M. Czugler, P. Ábrányi-Balogh, G. Keglevich, Beilstein J. Org. Chem. 2017, 13, 76-86. DOI:10.3762/bjoc.13.10

10. P. M. Mumford, G. J. Tarver, M. Shipman, J. Org. Chem. 2009, 74, 3573-3575. DOI:10.1021/jo9004958

11. W. Han, P. Mayer, A. R. Ofial, Adv. Synth. Catal. 2010, 352, 1667-1676. DOI:10.1002/adsc.201000092

12. M. K. Kolli, P. Elamathi, G. Chandrasekar, V. R. Katta, G. Balvantsinh Raolji, Synth. Commun. 2018, 48, 638-649. DOI:10.1080/00397911.2017.1385083

13. Y. Gao, Z. Huang, R. Zhuang, J. Xu, P. Zhang, G. Tang, Y. Zhao, Org. Lett. 2013, 15, 4214-4217. DOI:10.1021/ol4019419

14. W. Fan, Y. Queneau, F. Popowycz, RSC Adv. 2018, 8, 3149631501. DOI:10.1039/C8RA05983G

15. H. Sun, F. Z. Su, J. Ni, Y. Cao, H. Y. He, K. N. Fan, Angew. Chem. 2009, 121, 4454-4457. DOI:10.1002/ange.200900802 
16. Â. de Fatima, T. C. Braga, L. da S. Neto, B. S. Terra, B. G. F. Oliveira, D. L. da Silva, L. V. Modolo, J. Adv. Res. 2015, 6, 363-373. DOI:10.1016/j.jare.2014.10.006

17. H. Qu, X. Li, F. Mo, X. Lin, Beilstein J. Org. Chem. 2013, 9, 2846-2851. DOI:10.3762/bjoc.9.320

18. Z.-L. Shen, X.-P. Xu, S.-J. Ji, J. Org. Chem. 2010, 75, 11621167. DOI:10.1021/jo902394y

19. S. S. Mansoor, S. S. Shafi, S. Z. Ahmed, Arab. J. Chem. 2016, 9 , S846-S851. DOI:10.1016/j.arabjc.2011.09.018

20. L. M. Ramos, A. Y. Ponce de Leon y Tobio, M. R. dos Santos, H. C. B. de Oliveira, A. F. Gomes, F. C. Gozzo, A. L. de Oliveira, B. A. D. Neto, J. Org. Chem. 2012, 77, 10184-10193. DOI:10.1021/jo301806n

21. X.-H. Chen, X.-Y. Xu, H. Liu, L.-F. Cun, L.-Z. Gong, J. Am. Chem. Soc. 2006, 128, 14802-14803. DOI:10.1021/ja065267y

22. M. Moosavifar, C. R. Chim. 2012, 15, 444-447. DOI:10.1016/j.crci.2011.11.015

23. M. Rahman, A. Majee, A. Hajra, J. Heterocycl. Chem. 2010, 47, 1230-1233. DOI:10.1002/jhet.415

24. R. Fu, Y. Yang, W. Lai, Y. Ma, Z. Chen, J. Zhou, W. Chai, Q. Wang, R. Yuan, Synth. Commun. 2015, 45, 467-477.

DOI:10.1080/00397911.2014.976346

25. B. Mohammadi, F. K. Behbahani, Mol. Divers. 2018, 1-42.

26. C. K. Prier, D. A. Rankic, D. W. MacMillan, Chem. Rev. 2013, 113, 5322-5363. DOI:10.1021/cr300503r

27. J. W. Tucker, C. R. Stephenson, J. Org. Chem. 2012, 77, 16171622. DOI:10.1021/jo202538x

28. N. A. Dangroo, T. Ara, B. A. Dar, M. Khuroo, Catal. Commun. 2019, 118, 76-80. DOI:10.1016/j.catcom.2018.10.006

29. N. Dangroo, A. Dar, R. Shankar, M. Khuroo, P. Sangwan, Tetrahedron Lett. 2016, 57, 2717-2722.

DOI:10.1016/j.tetlet.2016.05.003

30. N. A. Dangroo, A. A. Dar, B. A. Dar, Tetrahedron Lett. 2014, 55, 6729-6733. DOI:10.1016/j.tetlet.2014.09.123

31. N. Chalotra, A. Ahmed, M. A. Rizvi, Z. Hussain, Q. N. Ahmed, B. A. Shah, J. Org. Chem. 2018, 83, 14443-14456.

DOI:10.1021/acs.joc.8b02193
32. S. Sultan, M. A. Rizvi, J. Kumar, B. A. Shah, Chem. Eur. J. 2018, 24, 10617-10620. DOI:10.1002/chem.201801628

33. F. Kouser, V. K. Sharma, M. Rizvi, S. Sultan, N. Chalotra, V. K. Gupta, U. Nandi, B. A. Shah, Tetrahedron Lett. 2018, 59, 2161-2166. DOI:10.1016/j.tetlet.2018.04.046

34. (a) B. S. Kumara, A. U. Ravi Sankara, C. S. Reddy, S. K. Nayak, C. Naga Rajua, ARKIVOC 2007, (xiii), 155-166. (b) C. Venkateswarlu, P. V. V. Satyanarayana, C. V. Nageswara Rao, C. Naga Raju, C. Sampath, OCAIJ 2011, 7, 320-324. (c) J. T. Hou, J. W. Gao, Z. H. Zhang, Appl. Organometal. Chem. 2011, 25, 47-53. DOI:10.1002/aoc.1687

(d) A. A. Jafari, S. Amini, F. Tamaddon, J. Iran. Chem. Soc. 2013, 10, 677-684. DOI:10.1007/s13738-012-0200-6

(e) M. A. Nasseri, M. Sadeghazdeh, J. Chem. Sci. 2013, 125, 537-544. DOI:10.1007/s12039-013-0403-0

(f) T. Bhattacharya, B. Majumdar, D. Dey, T. K. Sarma, RSC Adv. 2014, 4, 45831-45837. DOI:10.1039/C4RA08533G

(g) S. Sobhani, F. Khakzad, Appl. Organometal. Chem. 2017, 31, e3877. DOI:10.1002/aoc.3877

(h) S. U. Deshmukh, K. R. Kharat, A. R. Yadav, S. U. Shisodia, M. G. Damale, J. N. Sangshetti, R. P. Pawar, Chemistry Select 2018, 3, 5552-5558. DOI:10.1002/slct.201800798

(i) S. Poola, M. R. Nadiveedhi, S. Sarva, M. Gundluru, S. Nagaripati, M. S. Shaik, P. Kotha, N. Chamarthi, S. R. Cirandur, Med. Chem. Res. 2019, 28, 528-544.

DOI:10.1007/s00044-019-02302-y

35. (a) M. Yadollahi, H. Hamadi, V. Nobakht, Appl. Organometal. Chem. 2019, 33, e4629 (10 pages). DOI:10.1002/aoc.4819

(b) H. G. O. Alvim, T. B. de Lima, H. C. B. de Oliveira, F. C. Gozzo, J. L. de Macedo, P. V. Abdelnur, W. A. Silva, B. A. D. Neto, ACS Catal. 2013, 3, 1420-1430.

DOI: $10.1021 / \operatorname{cs} 400291 \mathrm{t}$

(c) E. A. Gilandeh, A. Yahyazadeh, M. A. Hashjin, RSC Adv. 2018, 8, 40243-40251. DOI:10.1039/C8RA08622B

36. W. Huang, B. C. Ma, H. Lu, R. Li, L. Wang, K. Landfester, K. A. Zhang, ACS Catalysis. 2017, 7, 5438-5442.

DOI:10.1021/acscatal.7b01719

\section{Povzetek}

V članku opisujemo tandemsko enolončno neposredno pretvorbo benzil alkoholov v $a$-aminofosfonate in dihidropirimidone, ki poteka pod pogoji brez uporabe topil. Metoda temelji na fotooksidaciji benzilnih alkoholov do benzaldehidov pod vplivom UV svetlobe ob uporabi amonijevega perklorata, brez uporabe kovinskih katalizatorjev. Tej prvi reakciji sledi Kabachnik-Fieldsova ali Biginellijeva reakcija. Reakcije potekajo pod zmernimi pogoji, brez dodatkov kovin, s pestrim naborom izhodnih substratov. Kontrolne eksperimente smo izvedli, da bi ugotovili vlogo amonijevega perklorata in molekularnega kisika kot oksidanta. Eksperimenti, izvedeni v prisotnosti TEMPO in ostalih lovilcev radikalov, so pokazali, da reakcijski mehanizem verjetno temelji na radikalskih procesih.

Except when otherwise noted, articles in this journal are published under the terms and conditions of the Creative Commons Attribution 4.0 International License 